\title{
Transcriptomic profiling of Bacillus amyloliquefaciens FZB42 in response to maize root exudates
}

Ben Fan ${ }^{1,2}$, Lilia C Carvalhais ${ }^{2}$, Anke Becker ${ }^{3}$, Dmitri Fedoseyenko ${ }^{4}$, Nicolaus von Wirén ${ }^{4}$ and Rainer Borriss ${ }^{2,5^{*}}$

\begin{abstract}
Background: Plant root exudates have been shown to play an important role in mediating interactions between plant growth-promoting rhizobacteria (PGPR) and their host plants. Most investigations were performed on Gram-negative rhizobacteria, while much less is known about Gram-positive rhizobacteria. To elucidate early responses of PGPR to root exudates, we investigated changes in the transcriptome of a Gram-positive PGPR to plant root exudates.
\end{abstract}

Results: Bacillus amyloliquefaciens FZB42 is a well-studied Gram-positive PGPR. To obtain a comprehensive overview of FZB42 gene expression in response to maize root exudates, microarray experiments were performed. A total of 302 genes representing 8.2\% of the FZB42 transcriptome showed significantly altered expression levels in the presence of root exudates. The majority of the genes (261) was up-regulated after incubation of FZB42 with root exudates, whereas only 41 genes were down-regulated. Several groups of the genes which were strongly induced by the root exudates are involved in metabolic pathways relating to nutrient utilization, bacterial chemotaxis and motility, and non-ribosomal synthesis of antimicrobial peptides and polyketides.

Conclusions: Here we present a transcriptome analysis of the root-colonizing bacterium Bacillus amyloliquefaciens FZB42 in response to maize root exudates. The 302 genes identified as being differentially transcribed are proposed to be involved in interactions of Gram-positive bacteria with plants.

\section{Background}

Plant growth-promoting rhizobacteria (PGPR) are generally referred to as a heterogeneous group of bacteria which colonize the rhizoplane and/or rhizosphere and stimulate plant growth $[1,2]$. PGPR have been commercially exploited as biofertilizers to improve the yield of crops. Some PGPR have also been successfully used as biocontrol agents to prevent plant diseases caused by phytopathogens, especially some soil-borne diseases [3-5]. The investigations on the interactions between PGPR and their host plants can not only contribute to our understanding of eukaryote-prokaryote relationships, but also have fundamental implications for designing new strategies to promote agricultural plant production.

\footnotetext{
*Correspondence: rainer.borriss@rz.hu-berlin.de

${ }^{2}$ Institut für Biologie Bakteriengenetik, Humboldt Universität Berlin, Chausseestrasse 117, D-10115 Berlin, Germany

${ }^{5}$ ABiTEP GmbH, Glienicker Weg 185, D-12489 Berlin, Germany

Full list of author information is available at the end of the article
}

In recent years, there is increasing evidence that plant root exudates play a key role in plant-microbe interactions [6-10]. Root exudates consist of an enormous range of compounds, among which some can attract beneficial associative bacteria to overcome stress situations [8]. On the other hand, root exudates contain low molecular-weight carbon such as sugars and organic acids that primarily act as energy sources for rhizobacteria and shape bacterial communities in the rhizosphere [11]. To date, however, it remains unclear how root exudates exert differential effects on rhizobacteria and which mechanisms or pathways make rhizobacteria responsive to plant root exudates.

Transcriptome analyses are an efficient approach to study host-microbe interactions at a wider scale. So far, the use of this approach to analyse bacterial gene expression has been extensively used to study pathogenic microbes infecting their host [12]. Only a few studies were performed with beneficial PGPR [13-15]. Several

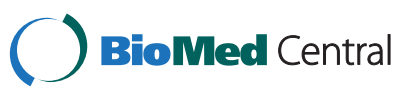


genes from Pseudomonas aeruginosa involved in metabolism, chemotaxis and type II secretion were identified to respond to sugar-beet root exudates [13]. In another study, it has been suggested that the availability of particular metabolites in root exudates, especially amino acids and aromatic compounds, support Pseudomonas putida to colonize the rhizosphere [14]. Rhizobium leguminosarum was grown in the rhizospheres of its hostlegume pea and two other non-host plants, alfalfa and sugar-beet. Although numerous sugar and putative complex carbohydrate transport systems are induced in the rhizosphere, they are less important carbon sources than organic acids. A common core of rhizosphere-induced genes was identified [15].

So far, studies on the impact of root exudates on PGPR, have been conducted with Gram-negative bacteria, mainly Azospirillum and Pseudomonas spp. $[16,17]$. Related studies performed with Gram-positive PGPR are still missing. Owing to differences in lifestyle and physiology, Gram-positive and Gram-negative rhizobacteria may use distinct mechanisms when interacting with plants. Due to their ability to produce durable endo-spores, bacilli are now preferred in manufacturing biofertilizer formulations [18], however, their successful application is still hampered by a lack of knowledge about factors determining interactions between plants and those bacteria, especially root colonization is far from being completely understood.

Bacillus amyloliquefaciens FZB42 is a plant rootcolonizing Gram-positive PGPR. A series of studies has elucidated several aspects of this rhizobacterium, particularly the molecular basis of its plant growth-promoting activity, which is mainly based on the production of secondary metabolites suppressing competitive microbial pathogens occurring in the plant rhizosphere, the secretion of the plant growth hormone auxin, and the synthesis of volatiles stimulating plant growth and induced systemic resistance (ISR) [19-21]. In the case of Gram-positive PGPR, however, it is still not clear how they maneuver their gene expression when exposed to plant-derived compounds. To address this question, the commercially established FZB42 wild type strain from Bacillus amyloliqufaciens was tested in this study for its transcriptomic responses to maize root exudates using a two-color DNA microarray system.

\section{Results and discussion}

\section{Composition of maize root exudates}

Maize root exudates were collected from axenic hydroponic cultures and analysed by HPLC for organic acids, amino acids, and oligosaccharides, which have been previously reported to be among the major ingredients in root exudates [8,22-24].

Among the compounds detected, in particular organic acids such as malic acid, malonic acid, succinic acid and trans-aconitic acid, were present at highest concentrations (Figure 1). Corroborating an earlier report [25], we found that lactic acid was a main constituent of maize root exudates. A variety of amino acids was also detected. Glucose and melibiose were the most prominent sugars occurring in root exudates. According to this analysis, most low-molecular weight organic carbon appeared to be present in the form of organic acids.

\section{Overall changes in gene expression in response to root exudates}

In the rhizosphere, root exudates may occur at high concentrations in certain microenvironments, e.g. in vicinity of root tips [26], but their concentration in specific niches of the environment is unknown. Therefore, the

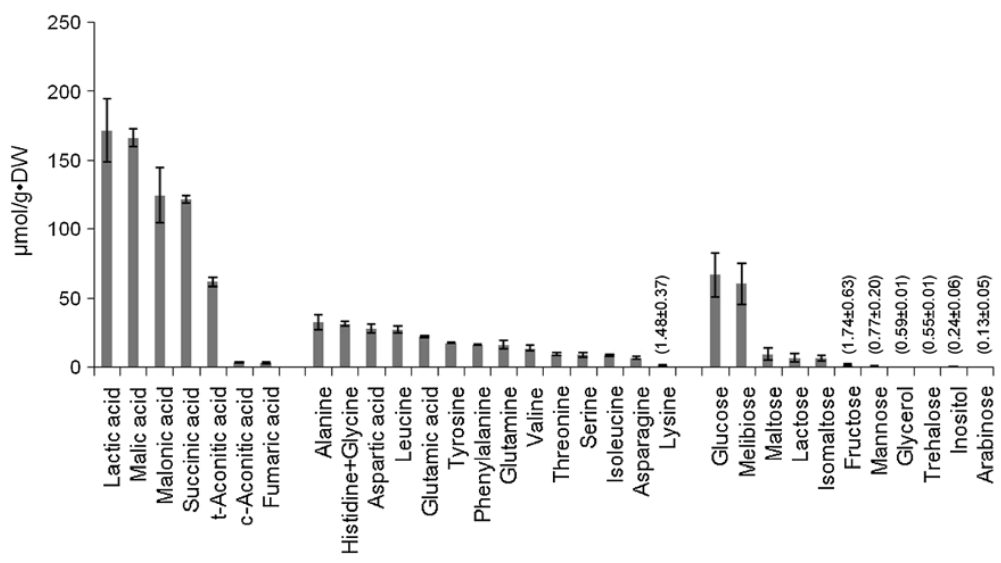

Figure 1 Composition and concentration of the maize root exudates. Exudates collected from the roots of maize seedlings were assayed by HPLC. Organic acids, amino acids, and carbohydrates were quantified and those which had a concentration of $>0.1 \mu m o l$ g-1 (dry weight) were included in the graph. Proline, a known constituent of maize root exudate, was not detected since the derivatization reagent (OPA) used reacts only with primary amino groups. 
choice of a physiologically relevant concentration of exudates to be used for microarray experiments can only be tentative. Based on a previous study on changes in the proteomics of FZB42 [27], three exudate concentrations $\left(0.25 \mathrm{gl}^{-1}, 0.5 \mathrm{gl}^{-1}\right.$ and $\left.1.0 \mathrm{gl}^{-1}\right)$ were applied to liquid cultures of FZB42, and bacterial cells were harvested for RNA extraction at two growth stages $\left(\mathrm{OD}_{600}=1.0\right.$ and $\mathrm{OD}_{600}=3.0$ ). For simplicity, the two population densities were referred to as OD1.0 and OD3.0 throughout this paper, respectively. A concentration of $0.25 \mathrm{gl}^{-1}$ was sufficient to result in a significant response of FZB42 transcriptome. When bacteria were cultured at OD3.0 the number of up-regulated genes gradually decreased with increasing root exudate concentration, suggesting that some compounds need to occur at lower abundance to induce gene expression, or that gene transcription in general may be suppressed at high concentrations of some exudates components (Figure 2). More transcripts were significantly altered $(\mathrm{q} \leq 0.01)$ at the transition to the stationary growth (OD 3.0) than at the exponential growth (OD1.0) (Figure 2), suggesting that OD 3.0 was a sampling point which reflected more clearly the effect of root exudates on FZB42 than OD1.0. For these reasons, the exudate concentration of $0.25 \mathrm{gl}^{-1}$ and the OD3.0 for harvesting of cells were used for all subsequent microarray experiments.

Six independent experiments were performed and the genes whose transcription fulfilled the condition of yielding a $\mathrm{q}$ value not greater than $0.01(\mathrm{q} \leq 0.01)$ and a fold change not less than $1.5(\mathrm{FCH} \geq 1.5)$ were regarded as being significantly influenced by root exudates. A total of 302 genes, representing $8.2 \%$ of the FZB42 transcriptome, were significantly regulated in their transcript levels by the applied root exudates (see supplemental material Additional file 1: Tables S1, S2, and S3). The majority of these genes (261 genes) was up-regulated, whereas only 41 genes were down-regulated (Figure 3 ). Although most of the regulated genes have been functionally annotated, a significant proportion ( $23 \%)$ remained of unknown function, among which 19 genes were unique for FZB42. In addition, 44 genes $(\sim 15 \%)$ encoded either hypothetical proteins or proteins with putative functions (Figure 3). The distribution in various functional categories of all the gene with known (189 genes) or putative (44 genes) products are summarized in Figure 4.

\section{Validation of microarray result by real-time PCR}

Nine up-regulated genes with different levels of fold changes in expression (1.5 5.2 fold) were chosen to be evaluated by quantitative real-time PCR. All these genes were confirmed to be significantly up-regulated in the presence of root exudates (Figure 5). The fold change of each gene revealed by real-time PCR was similar to that obtained in the microarray experiments (Figure 5). In summary, the real-time PCR suggested that the microarray data were reliable.

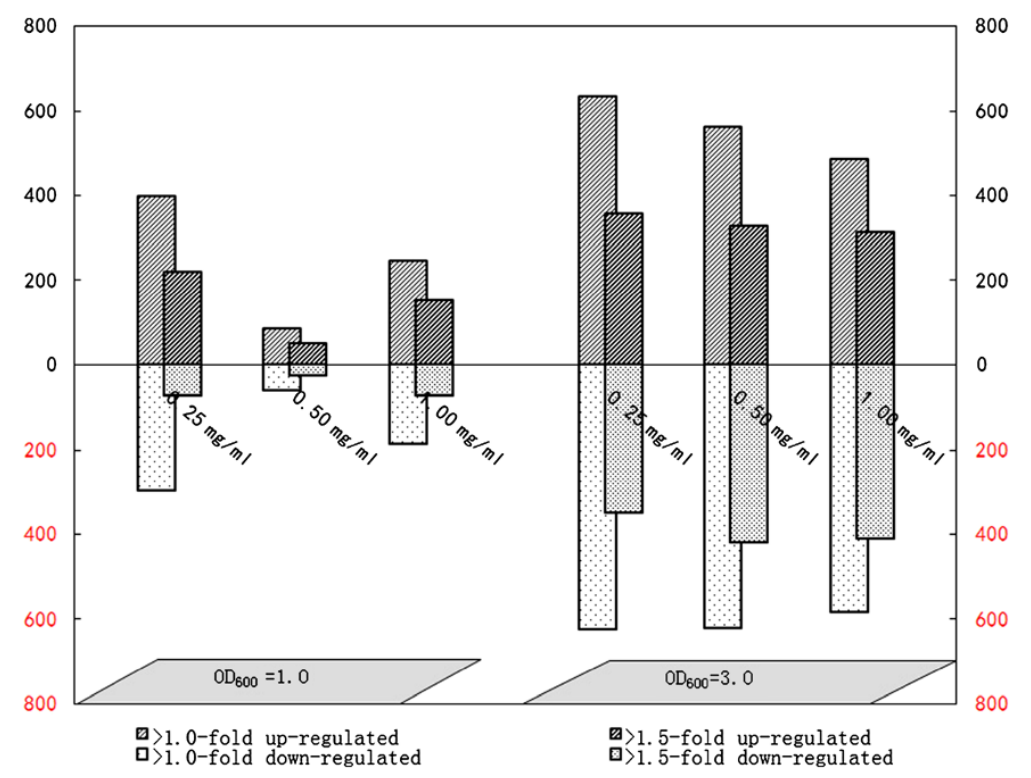

Figure 2 Number of FZB42 genes altered in transcription in response to root exudates at different exudate concentrations and cell densities. Maize root exudates were supplemented in three concentrations $(0.25 \mathrm{mg} / \mathrm{ml}, 0.5 \mathrm{mg} / \mathrm{ml}$ and $1.0 \mathrm{mg} / \mathrm{ml})$ to FZB42 cultures and total RNA was prepared from the bacterial cells harvested at two optical densities $\left(\mathrm{OD}_{600}=1.0\right.$ and $\left.\mathrm{OD}_{600}=3.0\right)$. Genes significantly altered in transcription ( $q \leq 0.01$ and fold change $\geq 1.5$ ) by presence of root exudates are represented in the figure. 


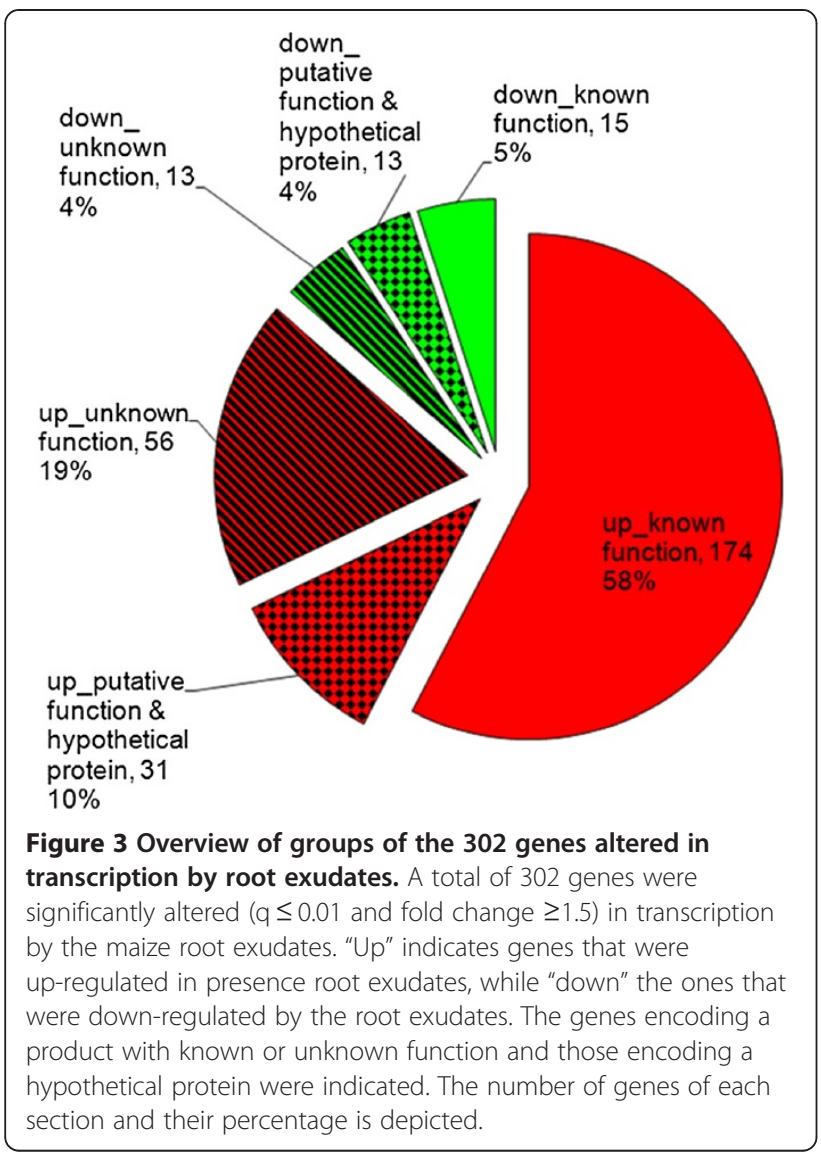

The regulated genes with known function

Among the 302 genes with significantly altered expression by root exudates, 189 were annotated with known functions. These were categorized into various classes [28], such as cell envelope and cellular processes, intermediary metabolism, information pathway and other functions . In these categories, three groups (Table 1) contained the largest numbers of genes and at least one third of the genes within these groups had a fold change of $\geq 2.0$. This suggests that these three groups of genes were strongly affected by root exudates:

i) The transcription of 46 genes involved in carbon and nitrogen utilization was altered in response to root exudates, with 43 of them being up-regulated. These 46 genes were involved in different aspects of the metabolism of carbohydrates, amino acids and related metabolites. To obtain a more comprehensive understanding of their relevance in the metabolic context, the genes were mapped into the KEGG pathway and a representation of metabolic pathways was constructed (Figure 6). A total of 12 genes encoding enzymes involved in the EmbdenMeyerhof-Parnas (EMP) pathway (including pgi encoding for glucose-6-phosphate isomerase) and the TCA cycle were significantly up-regulated. These genes covered almost the entire glycolysis and TCA pathway.
Nearly a quarter of the genes with altered transcription (46 out of 189) were involved in uptake or utilization of nutrients. This observation corroborated that root exudates serve as energy sources in the interaction between roots and rhizobacteria.

Among the up-regulated genes, $g l v A, g l v \mathrm{C}$ and $g l v R$ showed the highest fold change $(g l v A$ : 5.2 -fold up-regulated, $g l v C$ : 2.5-fold up-regulated, $g l v R$ : 4.4-fold up-regulated). The enhancement of $g l v A$ expression was also validated by real-time PCR as well as by the proteomic data (unpublished). The three genes comprise the $g l v$ operon $(g l v A-g l v R-g l v C)$, which is responsible for maltose dissimilation and positively regulated by maltose [29] The significant up-regulation of these genes indicated that maltose was present in the exudates, which was confirmed by the HPLC analysis (Figure 1).

The genes involved in inositol metabolism (iolA, iolB, iolC, iolD, iolE, iolF, iolG, ioll, iolS) were also up-regulated, mainly with a fold change of $\geq 2.0$ (Figure 6). Except iolS, which is involved in the regulation of inositol catabolism, the other eight genes are members of the iol operon. The increased transcription of iolA and iolD was further confirmed by real-time PCR whereas the enhancement of iolB and iolL was validated by a proteomics approach (unpublished data). The activation of nine genes indicated the presence of inositol in the exudates, which has also been verified by HPLC.

ii) A second group of genes with a higher fold change were those associated with sensing, chemotaxis, motility and biofilm formation (Table 2). These processes are crucial for bacterial colonization of roots. The recognition of signals released from roots and rhizobacteria is the first step of the establishment of a mutual cross-talk [30]. Once plant signals have been perceived, bacteria move towards the plant root to establish in the rhizosphere [31-34]. Bacterial motility in the rhizosphere involves several processes such as chemotaxis, flagelladriven motility, swarming, and production of surfactants [35-38]. The observed transcriptional changes of genes required for chemotaxis (cheC, cheD) and motility (hag, $f l i D$, fliP and $f l g M$ ) indicated that root exudates contain compounds that induce attraction of FZB42 cells to roots.

Biofilm formation has been documented to be involved in directing or modulating efficient colonization by PGPR $[39,40]$. Biofilms can also provide the plant root system with a protective barrier against attack of pathogenic microbes [35]. Two B. amyloliquefaciens genes involved in biofilm formation, ycmA and luxS, were enhanced by maize root exudates (Table 2, Additional file 1: Table S1). The gene luxS, required for synthesis of the quorum-sensing signaling molecule autoinducer2 (AI-2) [41], is involved in biofilm formation of pathogenic Streptococcus species [42-44] and the 


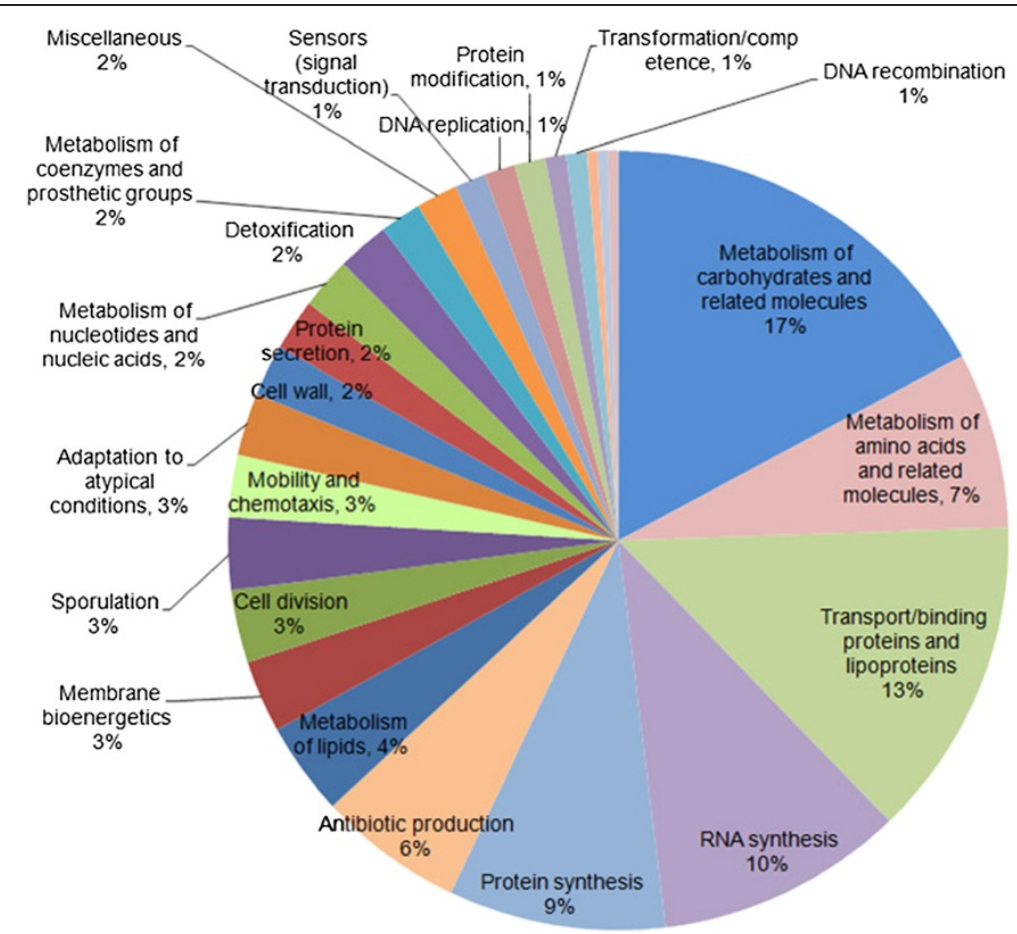

Figure 4 Distribution in various functional categories of the genes altered in transcription by root exudates. Among the 302 genes altered in transcription by maize root exudates at OD3.0, those with known (189 genes) or putative (44 genes) products were classified according to their function. The percentage of each group is indicated.

probiotic B. subtilis natto [45]. The gene $y c m A$ has also been indentified to be involved in facilitating biofilm formation $[46,47]$. The increased transcription of luxS and $y \mathrm{cmA}$ indicated that biofilm formation of FZB42 could be enhanced by some compounds present in root exudates. iii) The third functional group with the highest number of genes induced by root exudates was associated with the non-ribosomal synthesis of secondary metabolites with antimicrobial action (Table 3). Producing secondary metabolites suppressing deleterious microbes in the rhizosphere is an established mechanism of

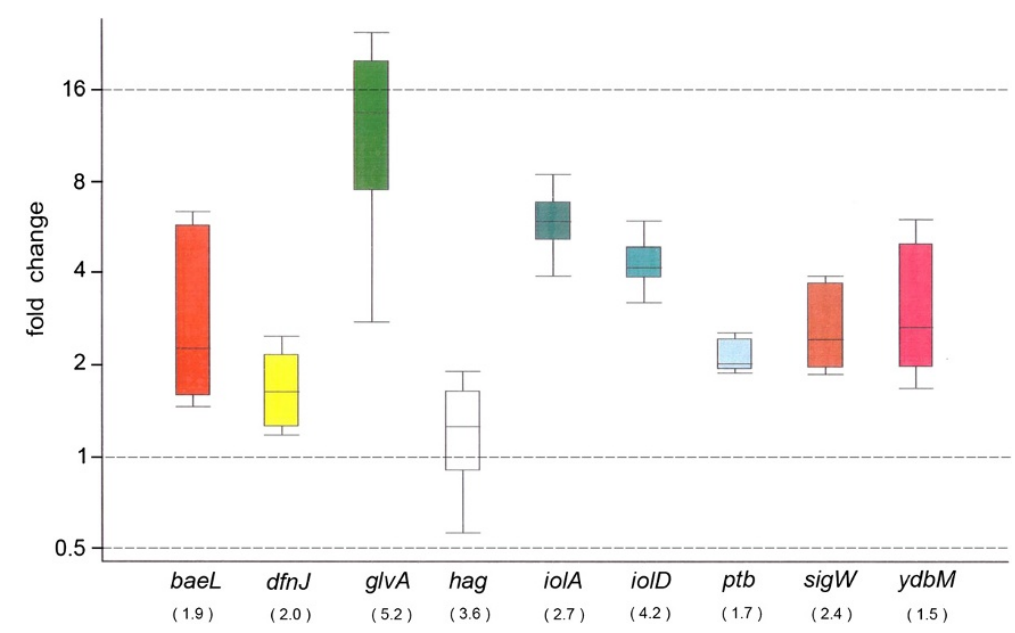

Figure 5 Fold-change of differentially expressed genes selected for validation by Real-time PCR. The fold changes revealed by real-time PCR of the selected genes were determined using the software REST. Three repeats were performed for each gene. For comparison, the fold changes obtained in microarray analysis were shown in parenthesis below each specific gene. The boxes represent the distance between the 25th and the 75th percentile. The lines in the boxes represent the median gene expression. Whiskers represent the minimum and maximum observations. 
Table 1 Functional categories* of the FZB42 genes significantly regulated by the maize root exudates and with known functions

\begin{tabular}{|c|c|}
\hline Classification code_Functional category & $\begin{array}{l}\text { Nr. of the } \\
\text { genes included }\end{array}$ \\
\hline 1_cell envelope and cellular processes & 58 \\
\hline 1.7_Cell division & 6 \\
\hline 1.1_Cell wall & 5 \\
\hline 1.4_ Membrane bioenergetics & 7 \\
\hline 1.5_Mobility and chemotaxis & 6 \\
\hline 1.3_ Sensors (signal transduction) & 2 \\
\hline 1.6_Protein secretion & 5 \\
\hline 1.8_Sporulation & 7 \\
\hline 1.1_Transformation/competence & 2 \\
\hline 1.2_ Transport/binding proteins and lipoproteins & 18 \\
\hline 2_intermediary metabolism & 59 \\
\hline $\begin{array}{l}2.1 \_ \text {Metabolism of carbohydrates and } \\
\text { related molecules }\end{array}$ & 34 \\
\hline $\begin{array}{l}2.2 \text { Metabolism of amino acids and } \\
\text { related molecules }\end{array}$ & 12 \\
\hline 2.5_ Metabolism of coenzymes and prosthetic groups & 4 \\
\hline 2.4_ Metabolism of lipids & 5 \\
\hline 2.3_ Metabolism of nucleotides and nucleic acids & 4 \\
\hline 3_information pathways & 45 \\
\hline 3.3_ DNA recombination & 1 \\
\hline 3.1_ DNA replication & 3 \\
\hline 3.8_ Protein modification & 2 \\
\hline 3.7_Protein synthesis & 20 \\
\hline 3.6_ RNA modification & 1 \\
\hline 3.5_ RNA synthesis & 18 \\
\hline 4_other functions & 27 \\
\hline 4.1_ Adaptation to atypical conditions & 6 \\
\hline 4.2_ Detoxification & 4 \\
\hline 4.6_Miscellaneous & 3 \\
\hline 4.4_ Phage-related functions & 1 \\
\hline 4.3_Antibiotic production & 13 \\
\hline In total & 189 \\
\hline
\end{tabular}

biocontrol adopted by B. amyloliquefaciens FZB42 on plants $[19,48,49]$. The majority of the induced genes are devoted to the synthesis of two polyketide antibiotics, bacillaene and difficidin. Some components in the exudates could stimulate the production of these two antibiotics, which have been demonstrated to be able to protect orchard trees from fire blight disease caused by Erwinia amylovora [49].

Another two genes, $m \ln H$ and $f e n E$, were also induced, which are known to participate in non-ribosmal biosynthesis of macrolactin and fengycin, respectively. Macrolactin, a polyketide product found in FZB42, has activity against some Gram-positive bacteria [50], while fengycin can act against phytopathogenic fungi in a synergistic manner with bacillomycin D $[19,51]$.

In addition, two genes encoding surfactin synthetase were also activated by root exudates (Table 3). Surfactin is one of Bacillus cyclic lipopeptides, displaying antiviral and antibacterial activities. In Arabidopsis it has been shown that the ability of Bacillus to synthesize surfactin can reduce the invasion of Pseudomonas syringae [30]. although it is not yet clear whether the protective effect resulted directly from the antibacterial activity of surfactin or from its biofilm-related properties. Surfactin is crucially involved in the motility of Bacillus by reducing surface tensions $[36,37,52]$ and contributing to biofilm formation on Arabidopsis roots [30]. It has also been demonstrated that surfactin production of FZB42 was enhanced when colonizing the duckweed plant Lemna minor [21]. It can be expected that up-regulation of srfAC and srfAD may contribute to the protective role of surfactin against plant pathogens.

\section{The regulated genes with putative function}

Among the 302 genes significantly altered in transcription by root exudates, 44 were annotated to encode a putative enzyme or a hypothetical protein. Similar to the genes with known function, these 44 genes fell into three categories: metabolism of carbohydrates and related molecules, metabolism of amino acids and related molecules, and transport/binding proteins and lipoproteins (Additional file 1: Table S2). Some of the 44 genes were closely associated with plant-microbe interactions. For example, the transcription of $y d j L$, nowadays renamed $b d h A$, encoding acetoin reductase/butanediol dehydrogenase [53], was 1.5 -fold enhanced by root exudates. 2, 3-Butanediol is a volatile organic compound released by PGPR and able to promote significantly plant growth [54]. The expression of the gene epsE, residing in a 15-gene operon epsA-O, was also enhanced by root exudates. EpsE is involved in formation of biofilm by arresting flagellar rotation of cells embedded in biofilm matrix [55]. Another activated gene was $d f n Y$, which encodes a hypothetical protein. Like other induced genes known to be involved in antibiotic production such as $d f n F, d f n G$, $d f n I$ and $d f n J$ (Table 3), $d f n Y$ is part of the gene cluster responsible for synthesis of the polyketide antibiotic difficidin. It is worth mentioning that antibiotic production is energetically very costly and its strict control is a clear evolutionary advantage.

In contrast to a few genes significantly altered during the exponential phase (OD1.0), hundreds of genes were 


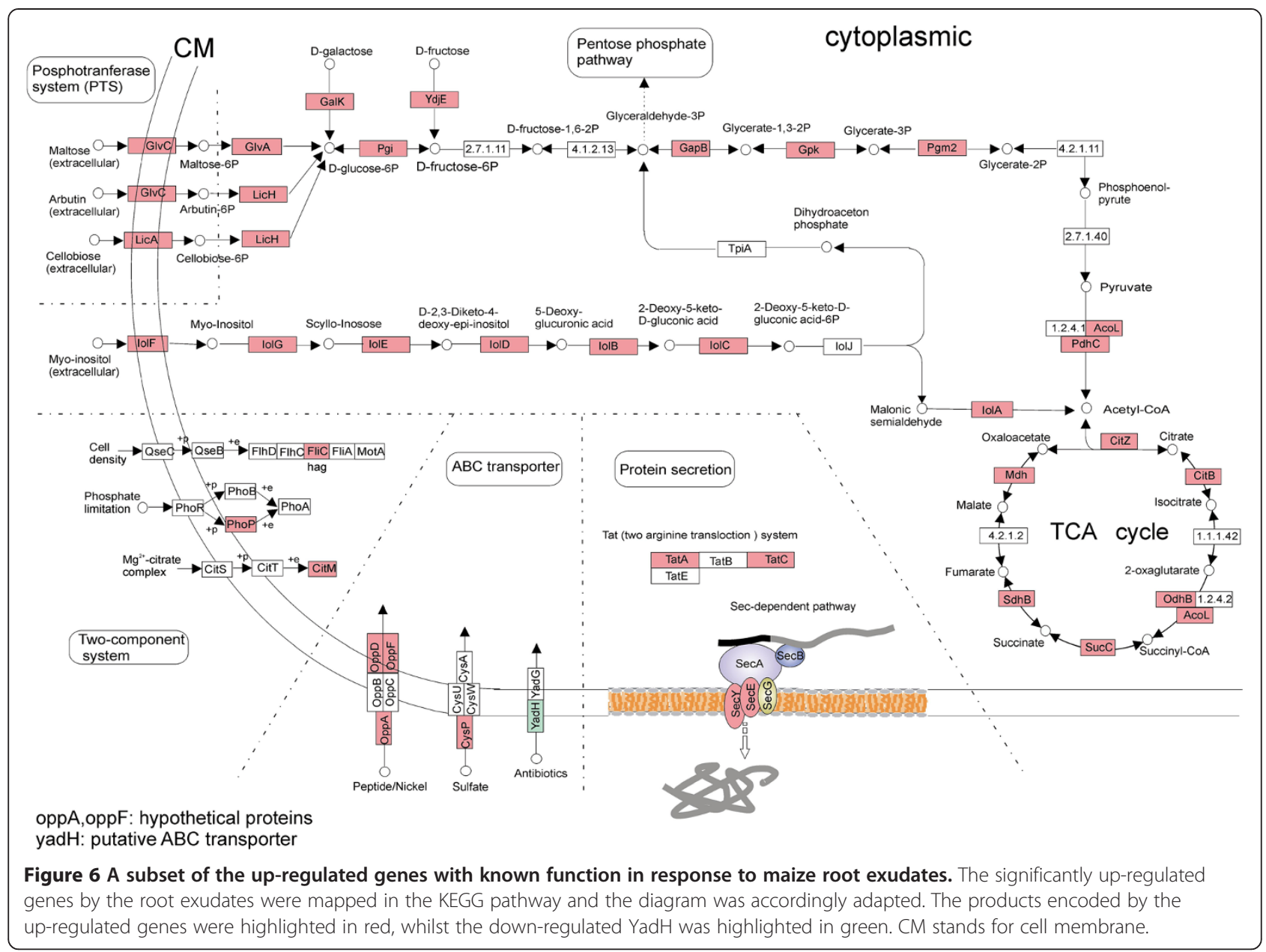

differentially expressed in presence of root exudates during transition to stationary growth phase (OD3.0). Such a difference may not be surprising. The transcription of most bacterial genes during the exponential growth phase is typically initiated by RNA polymerase holoenzyme carrying the housekeeping transcription factor $\sigma^{\mathrm{A}}$, while in the stationary phase, transcription is mainly accomplished by RNAP carrying alternative sigma

Table 2 FZB42 genes significantly induced by maize root exudates and involved in mobility and chemotaxis (Refer to experiment "Response to RE": E-MEXP-3421)

\begin{tabular}{lll}
\hline Gene & Fold change & Classification code_function involved \\
\hline flim & 2.0 & $1.5 \_$Mobility and chemotaxis \\
\hline fliP & 1.7 & $1.5 \_$Mobility and chemotaxis \\
\hline cheC & 1.7 & $1.5 \_$Mobility and chemotaxis \\
\hline cheD & -1.5 & $1.5 \_$Mobility and chemotaxis \\
\hline hag & 3.6 & $1.5 \_$Mobility and chemotaxis \\
\hline flgM & 1.7 & $1.5 \_$Mobility and chemotaxis \\
\hline luxS & 1.7 & $1.3 \_$Sensors (signal transduction) \\
\hline ymcA & 2.5 & $1.3 \_$Sensors (signal transduction) \\
\hline
\end{tabular}

Table 3 FZB42 genes which were significantly induced by maize root exudates and involved in antibiotic production (Refer to experiment "Response to RE": E-MEXP-3421)

\begin{tabular}{llc}
\hline Gene & Product & $\begin{array}{l}\text { Fold } \\
\text { change }\end{array}$ \\
\hline baeE & malonyl-CoA-[acyl-carrier protein] transacylase BaeE & 1.6 \\
\hline bael & enoyl-CoA-hydratase Bael & 2.2 \\
\hline baeL & polyketide synthase BaeL & 1.9 \\
\hline baeN & hybrid NRPS/PKS BaeN & 1.5 \\
\hline baeR & polyketide synthase BaeR & 2.3 \\
\hline$d f n J$ & modular polyketide synthase of type I DfnJ & 2 \\
\hline$d f n I$ & modular polyketide synthase of type I Dfnl & 1.7 \\
\hline$d f n G$ & modular polyketide synthase of type I DfnG & 2 \\
\hline dfnF & modular polyketide synthase of type I DfnF & 2.4 \\
\hline mInH & polyketide synthase of type I MlnH & 1.5 \\
\hline fenE & fengycin synthetase FenE & 1.5 \\
\hline srfAD & surfactin synthetase D SrfAD & 1.9 \\
\hline srfAC & surfactin synthetase C SrfAC & 1.7 \\
\hline
\end{tabular}


factors allowing to adapt to a permanently changing environment. The extracytoplasmic-function (ECF) sigma factor $\mathrm{W}$ was enhanced in presence of root-exudate (Figure 5). SigW is known as being expressed in early stationary growth-phase and induced by various cell wall antibiotics, alkaline shock, and other stresses affecting the cell envelope. It controls a large "antibiosis" regulon involved in mediating resistance to various antibiotics including fosfomycin and the antibiotic peptides sublancin and SdpC [56]. It has been observed that many virulence-associated factors influence the colonization, persistence and spreading mechanisms of the human pathogen Streptococcus pyogenes in a growth phasedependent manner [57-59]. Likewise, rhizobacteria may employ an early stationary phase-related mechanism to favor expression of those genes that mediate rhizosphere competence.

\section{Effect of soil extract}

To simulate in part the conditions that bacteria experience in the rhizosphere soil, 10\% soil extract was added to the culture media. Additional microarray experiments were performed in a similar way as before to investigate the effect of the soil extract on gene expression of FZB42. The result showed that no gene was significantly up-regulated by the soil extract during exponential growth phase of OD1.0, whereas five genes were repressed in the presence of the soil extract at OD3.0 (Table 4). This negligible number of genes that were differentially transcribed indicates that the supplement of a soil extract did not have major effects on gene transcription under the growth conditions used.

\section{Effect of exudates prepared from maize plants colonized by FZB42}

Typically, most root exudates studied were collected from plants grown in axenic systems. The release of root exudates is not only determined by the plant species, but also by plant age, physiological status, and the biotic environment that plants thrive including the rhizosphere microflora that influence the composition and quantity of root exudates [60-66]. It was reported that $P$. aeruginosa produces $\mathrm{N}$-acyl homoserine lactone (AHL) signaling compounds that induce changes in the root exudation of Medicago truncatula [67]. Exudate compounds that are specifically induced or repressed by rhizobacteria may in turn affect bacterial gene expression. Such an effect cannot be demonstrated using root exudates collected from a gnotobiotic system, therefore, a batch of "interaction exudates (IE)" was collected from maize roots which were previously inoculated with FZB42.

The transcriptional responses of FZB42 to the IE were compared with responses to the root exudates (RE) collected from axenic culture. No significant differences $(q \leq 0.01$ and $F C H \geq 1.5)$ were found between the effect of IE and RE at OD1.0, while four genes were differentially expressed at OD3.0 (Additional file 2: Table S5). When a less stringent selection filter was applied $(\mathrm{q} \leq 0.05$ and $\mathrm{FCH} \geq 1.5$ ), a total of nine genes were differentially expressed (Additional file 2: Table S5). The four genes, significantly enhanced in presence of FZB42 at maize roots, encode enzymes involved in the degradation of macromolecules or cellular compounds, such as ggt, nprE, clpP, RBAM00438 (ycs $N)$. Among all four genes, expression of the ggt gene was found most enhanced, bearing a fold change of 2.2 in presence of the rhizobacterium (Additional file 2: Table S5). GGT, $\gamma$ glutamyltranspeptidase (GGT) (EC 2.3.2.2) catalyzes the hydrolysis of $\gamma$-glutamyl compounds, such as glutathione (GSH), and the transfer of $\gamma$-glutamyl moieties to amino acids and peptides. The nprE gene, which is mainly expressed during early stationary phase, encodes extracellular neutral protease involved in degradation of proteins and peptides. The peptidase ClpP, encoded by the $c l p P$ gene, can associate with the ATPases $\mathrm{ClpC}$, ClpE, and $\mathrm{ClpX}$, thereby forming a substrate specific channel for several regulatory proteins directing spore formation or genetic competence in bacilli. RBAM00438 is a member of the aldo-keto reductases (AKRs) superfamily of soluble $\operatorname{NAD}(\mathrm{P})(\mathrm{H})$ oxidoreductases whose chief purpose is to reduce aldehydes and ketones to primary and secondary alcohols. At present, it remains questionable if those gene products are linked with any specific process triggered by the IE. The number of the genes obtained was much less than expected. We conclude that possible differences between the transcriptome responses to these

Table 4 FZB42 genes repressed by soil extract at OD3.0 (Refer to experiment "Response to SE": E-MEXP-3551)

\begin{tabular}{lcll}
\hline Gene & Fold change & Product & Function involved \\
\hline ypeQ & -2.6 & hypothetical protein YpeQ & unknown \\
\hline yurV & -2.4 & iron-sulfur cofactor synthesis protein nifU homolog YurV & miscellaneous \\
\hline iolS & -2.2 & inositol utilization protein S (lolS) & metabolism of carbohydrates and related molecules \\
\hline yaaA & -2.0 & conserved hypothetical protein YaaA & unknown \\
\hline ahpF & -2.0 & $\begin{array}{l}\text { alkyl hydroperoxide reductase (large subunit) and NADH } \\
\text { dehydrogenase AhpF }\end{array}$ & detoxification \\
\hline
\end{tabular}


two exudate samples are either very rare or too subtle to be revealed sufficiently by two-color microarrays.

One drawback of the present investigation is that some effects of the root exudates may have been masked by components of the $1 \mathrm{C}$ medium and therefore did not result in altered gene expression. On the other hand, using $0.25 \mathrm{mg}$ exudates per $\mathrm{ml}$ medium, some components in the exudates may have been diluted to a level at which they no longer show detectable effect on bacterial gene expression. It has been reported that the rhizosphere is a very heterogeneous soil volume, with some regions being "hotspots" of root exudation and bacterial colonization. In natural environments, bacterial populations are likely to be exposed to different concentration of exudates along the root axis $[68,69]$.

It needs to be mentioned that the exudates used in this study were a pooled mixture of the samples collected within seven days from maize roots (see Methods). It has not yet been described to which extent the composition of root exudates is affected by the developmental stage of a plant [70] and therefore the presented bacterial responses cannot be assigned to a particular physiological state of the host plant. This question may be addressed by performing bacterial transcriptome analyses in response to exudates collected at different time points during plant development. Such an approach may be helpful to elucidate the progression of the plantbacteria association during the plant development.

In summary, this microarray work reflects the interactions between a Gram-positive rhizobacterium and its host plant in a genome-scale perspective. Critical target genes and pathways for further investigations of the interaction were identified. Given the limited reports on transcriptomic analysis of rhizobacteria in response to their host plants [13-15], the results provided a valuable insight into PGPR behaviour in the rhizosphere. About $10 \%$ of the total number of genes were found upregulated in presence of root exudate during transition to stationary growth phase. In addition to the findings corroborating previous transcriptome analyses performed in Gram-negative bacteria, we could demonstrate that presence of root exudate induced expression of numerous genes involved in non-ribosomal synthesis of secondary metabolites with antifungal and antibacterial action. We hypothesize that competitive colonization at plant root surfaces by FZB42 might be supported by enhanced synthesis of antimicrobial compounds.

\section{Conclusions}

Using the data from six independent micro array experiments, differentially transcribed genes of the PGPR $B$. amyloliquefaciens FZB42 were identified and their known or putative functions were related to their associative behavior with regard to interactions with maize roots. A large group of genes specifically expressed suggested that root exudates serve primarily as a source of carbon and energy for FZB42. Another group of genes significantly induced by plant root exudates encode the non-ribosomal synthesis of antimicrobial secondary metabolites. It is possible that enhanced synthesis of antimicrobial compounds might suppress the competing phytopathogenic organisms growing within the plant rhizosphere. However, direct evidence for occurrence of those compounds in vicinity of plant rhizosphere remains to be accomplished. The addition of soil extracts to the growth medium showed no major effect on gene expression of FZB42. Similarly, the results obtained with the "interaction exudates" collected from the maize roots inoculated with FZB42 did not indicate altered effects on gene expression compared with that of common root exudates collected in the gnotobiotic system.

\section{Methods}

\section{Root exudates collection and analysis}

Maize seeds (Saaten-Union, Germany) were surfacesterilized and germinated as described previously [21]. Root exudates were collected from the maize seedlings grown in an axenic system with sterile water (1:1 distilled water and tap water, v/v). Forty germinated seeds harboring a main root of at least $2 \mathrm{~cm}$ length were transferred into test tubes filled with $2 \mathrm{ml}$ of autoclaved water, with the maize seeds being placed just above the water surface. The tubes were kept under sterile conditions and maintained in a plant growth room (16-h light/8-h dark) at $24^{\circ} \mathrm{C}$ for 8 days. In the first two days, water was supplemented to the tubes, and seedlings were pulled to a higher position to ensure that the maize seeds were always above the water surface as the roots elongated. From the third day on, the water containing the exudates was collected and the tubes were refilled with sterile water. Sampling was performed every day until the eighth day after transferring the seedlings. Each collection were kept separate, from which a $100 \mu \mathrm{L}$ aliquot was taken and spread on a solid LB media to check for contamination. The contaminated samples were discarded.

To collect the "interaction exudates (IE)", the germinated maize seeds were inoculated with FZB42 as described previously [21] before transferring the test tubes. Afterward the maize was grown and the exudates were prepared in the same way as described above.

The collected exudates were pooled, freeze-dried and stored at $-20^{\circ} \mathrm{C}$. Before use, the lyophilized exudates were weighted, and dissolved in a certain volume of distilled water. The obtained exudates solution was centrifuged to remove any insoluble constituents. The supernatant was filter-sterilized and the resulting stock 
exudates were stored in dark at $-80^{\circ} \mathrm{C}$. The final concentration of the exudates in the culture vessel was generally adjusted to $0.25 \mathrm{~g} \mathrm{~L}^{-1}$. Chemical analysis of the root exudates was performed as described previously [71]: amino acids were determined using a Shimadzu HPLC system. $40 \mu \mathrm{L}$ samples were derivatized with $160 \mu \mathrm{l}$ OPA (o-phthaldialdehyde) reagent and $20 \mu \mathrm{L}$ of the resulting mixture were injected and separated on a GROM-SIL OPA-3 column using solvent gradient elution by solvent A (25 mM phosphate buffer $\mathrm{pH} 7.2$ with $0.75 \%$ tetrahydrofuran) and solvent $B$ (methanol to acetonitrile to $25 \mathrm{mM}$ phosphate buffer 7.2 [35:15:50/v: v : v]). Gradient profile: $0-2 \mathrm{~min}, 0 \% \mathrm{~B} ; 2-10 \mathrm{~min}, 0 \%-50 \% \mathrm{~B} ; 10-$ 15 min, $50-60 \%$ B; $15-20$ min, $60-100 \%$ B; $20-25$ min, $100 \%$ B; $25-26$ min, $100 \%-0 \%$ B; $26-35$ min, 0\% B. The flow-rate was $1 \mathrm{~mL} \mathrm{~min}{ }^{-1}$. Subsequent fluorescence detection of the derivatives was performed at an excitation wavelength of $330 \mathrm{~nm}$ and $450 \mathrm{~nm}$. Organic acids were determined by means of ion chromatography (Dionex IonPac AS $11 \mathrm{HC}$ column) using a gradient ranging from $4 \mathrm{mM}$ to $80 \mathrm{mM} \mathrm{KOH}$. Organic acids were identified by comparison of retention time with known standards. Sugars were determined by GC-TOF-MS. A lyophilized $75 \mu \mathrm{L}$ aliquot of root exudates was dissolved in $50 \mathrm{~mL}$ methoxyamine hydrochloride in dry pyrididine and derivatized for $2 \mathrm{~h}$ at $37^{\circ} \mathrm{C}$ followed by $30 \mathrm{~min}$. treatment with $50 \mu \mathrm{L} \mathrm{N}$-methyl- $\mathrm{N}$-trifluoroacetamide at $37^{\circ}$ C. A volume of $1 \mu \mathrm{L}$ was injected into the GC column.

\section{Microarray design}

The Bam4kOLI microarray was designed based on the sequenced complete genome of $B$. amyloliquefaciens FZB42 [27] (Additional file 3: Table S6). The array contained 3931 50-70mer oligonucleotides representing predicted protein-encoding genes and a set of small non-coding RNA genes of FZB42. In addition, the array included stringency controls with $71 \%, 80 \%$ and $89 \%$ identity to the native sequences of five genes, $d n a A$, rpsL, rpsO, rpsP, and rpmI, to monitor the extent of cross hybridization. The array also contained alien DNA oligonucleotides for four antibiotic resistance genes $\left(\mathrm{Em}^{r}, \mathrm{Cm}^{r}, \mathrm{Nm}^{r}\right.$ and $\left.\mathrm{Spc}^{r}\right)$ and eight spiking controls as well as one empty control (nothing spotted). All oligonucleotide probes were printed in four replicates. Microarrays were produced and processed as described previously [72].

Oligonucleotides were designed using the Oligo Designer software (Bioinformatics Resource Facility, CeBiTec, Bielefeld University). Melting temperatures of the oligonucleotides were calculated based on $\% \mathrm{GC}$ and oligo length, ranging from $73^{\circ} \mathrm{C}$ to $83^{\circ} \mathrm{C}$ (optimal $78^{\circ} \mathrm{C}$ ). Salt concentration was set to $0.1 \mathrm{M}$. QGramMatch was used to analyse uniqueness of the oligos.

\section{Experimental design}

The experiment designs of FZB42 in response to various conditions are summarized in Additional file 3: Table S6. Independent experiments were used as biological replicates. In all comparisons dye-swap were carried out to minimize the effect of dye biases.

$1 \mathrm{C}$ medium $(0.7 \% \mathrm{w} / \mathrm{v}$ pancreatic digest of casein, $0.3 \% \mathrm{w} / \mathrm{v}$ papain digest of soya flour, $0.5 \% \mathrm{w} / \mathrm{v} \mathrm{NaCl}$ ) containing $0.1 \%$ glucose was used in all experiments. Except the controls of the experiment "Response to SE" (Additional file 3: Table S6), 10\% soil extract was also supplemented in the media. Soil extract was prepared by extracting $500 \mathrm{~g}$ dried, fertile garden soil with one litre distilled water for $2 \mathrm{hrs}$ and autoclaving. After cooling down, the supernatant was filtered with $0.22 \mu \mathrm{m}$ Nuclepore unit and then stored at $4^{\circ} \mathrm{C}$ until use.

\section{Total RNA preparation}

One overnight colony of FZB42 was inoculated into $1 \mathrm{C}$ medium plus $0.1 \%$ glucose and then shaken at $210 \mathrm{rpm}$ at $24^{\circ} \mathrm{C}$. After 14 hours the obtained preculture was used to inoculate a new $1 \mathrm{C}$ medium (containing $0.1 \%$ glucose) plus the corresponding solution to be studied (maize root exudates, soil extract, or interaction exudates. See Additional file 3: Table S6). The main cultures were grown at $24^{\circ} \mathrm{C}$ until they reached late exponential growth phase (OD 1.0) and/or the transition to stationary phase (OD3.0, see Additional file 4: Figure S1).

The FZB42 cells of OD1.0 or OD3.0 were harvested for preparation of total RNA. A volume of $15 \mathrm{ml}$ of the culture was mixed with $7.5 \mathrm{ml}$ "killing buffer" (20 mM Tris- $\mathrm{HCl}, 5 \mathrm{mM} \mathrm{MgCl} 2,20 \mathrm{mM} \mathrm{NaN3}, \mathrm{pH}$ 7.5) and then centrifuged at 5,000 rpm for 3 minutes at room temperature. The pellet was washed once more with $1 \mathrm{ml}$ "killing buffer" and then immediately frozen in liquid nitrogen. The frozen cell pellets were stored at $-80^{\circ} \mathrm{C}$ until RNA isolation.

Isolation of RNA was performed using the Nucleo Spin ${ }^{\circledR}$ RNA L (Macherey Nagel) according to the manufacturer's instructions. The isolated RNA was additionally digested with DNaseI to avoid possible trace DNA contamination. After ethanol precipitation RNA pellets were resuspended in $300 \mu \mathrm{l}$ RNase-free water. The concentration of total RNA was spectrophotometrically determined, whereas its quality was checked on a $1.5 \%$ RNA agarose gel in $1 \times$ MEN buffer $(20 \mathrm{mM}$ MOPS; 1 mM EDTA, $5 \mathrm{mM}$ NaAc; pH7.0) with $16 \%$ formaldehyde.

\section{Synthesis of labeled CDNA, hybridization and image acquisition}

Synthesis of first-strand cDNA, microarray hybridization and image acquisition were performed in $\mathrm{CeBiTec}$, the Center for Biotechnology at Bielefeld University. Briefly, 
aminoallyl-modified first-strand cDNAs were synthesized by reverse transcription according to DeRisi et al [73]. and then coupled with Cy3- and Cy5-N-hydroxysuccinimidyl ester dyes (GE Healthcare, Little Chalfont, UK). After hybridization using the HS4800 hybridization station (Tecan Trading AG, Switzerland), slides were scanned with a pixel size of $10 \mu \mathrm{m}$ using the LS Reloaded microarray scanner (Tecan Trading AG, Switzerland).

\section{Data processing}

The microarray data obtained was analysed by using the EMMA 2.8.2 software [74]. The mean signal intensity $\left(A_{\mathrm{i}}\right)$ was calculated for each spot using the formula $A_{\mathrm{i}}=$ $\log _{2}\left(R_{\mathrm{i}} G_{\mathrm{i}}\right)^{0.5} \quad$ [75]. $R_{\mathrm{i}}=I_{\operatorname{ch} 1(\mathrm{i})}-B g_{\operatorname{chl} 1(\mathrm{i})}$ and $G_{\mathrm{i}}=I_{\operatorname{ch} 2(\mathrm{i})}-$ $B g_{\mathrm{ch} 2(\mathrm{i})}$, where $I_{\mathrm{ch} 1(\mathrm{i})}$ or $I_{\mathrm{ch} 2(\mathrm{i})}$ is the intensity of a spot in channel 1 or channel 2, and $B g_{\text {ch1(i) }}$ or $B g_{\text {ch2(i) }}$ is the background intensity of a spot in channel1 or channel 2, respectively. The $\log _{2}$ value of the ratio of signal intensities (Mi) was calculated for each spot using the formula $M \mathrm{i}=\log _{2}(R \mathrm{i} / G \mathrm{i})$. Spots were flagged as "empty" if $R \leq 0.5$ in both channels, where $R=$ (signal mean-background mean)/background standard deviation [76]. The raw data were normalized by the method of LOWESS (locally weighted scattered plot smoothing). A significance test was performed by the method of false discovery rate (FDR) control and the adjusted p-value defined by FDR was called q-value [77,78].

An arbitrary cutoff, fold change $(\mathrm{FCH})$ greater than 1.5 , was applied to the genes with a q-value of $\leq 0.01$. Only those genes which meet both filter conditions $(q \leq 0.01 \& F C H \geq 1.5)$ were regarded to be significantly differentially expressed.

\section{Real-time PCR}

The first-strand cDNA was obtained by reverse transcription with RevertAid ${ }^{\mathrm{TM}}$ Premium Reverse Transcriptase (Fermentas, St. Leon-Rot, Germany), using random hexamers as primers. Oligonucleotide primers were designed by the software PrimerExpress and listed in supplemental materials (Additional files 1: Table S4). Real-time PCR was performed with $\mathrm{SYBR}^{\circledR}$ Green PCR Master Mix kit (Carlsbad, California, USA) using 7500 Fast Real-Time PCR System (Carlsbad, California, USA) according to the manufacturers' instructions. As an internal control, the housekeeping gene gyrA was used as its expression was not significantly altered in all microarray experiments. Three technical replicates were carried out for each target gene. Quantification was analysed based on the threshold cycle $(\mathrm{Ct})$ values as described by Pfaffl [79].

The raw data of the Micro-array experiments, described here, are available in the ArrayExpress database under the accession numbers: E-MEXP-3421, E-
MEXP-3550, E-MEXP-3551, E-MEXP-3553, E-MEXP3554, respectively (see also Additional file 3: Table S6).

\section{Additional files}

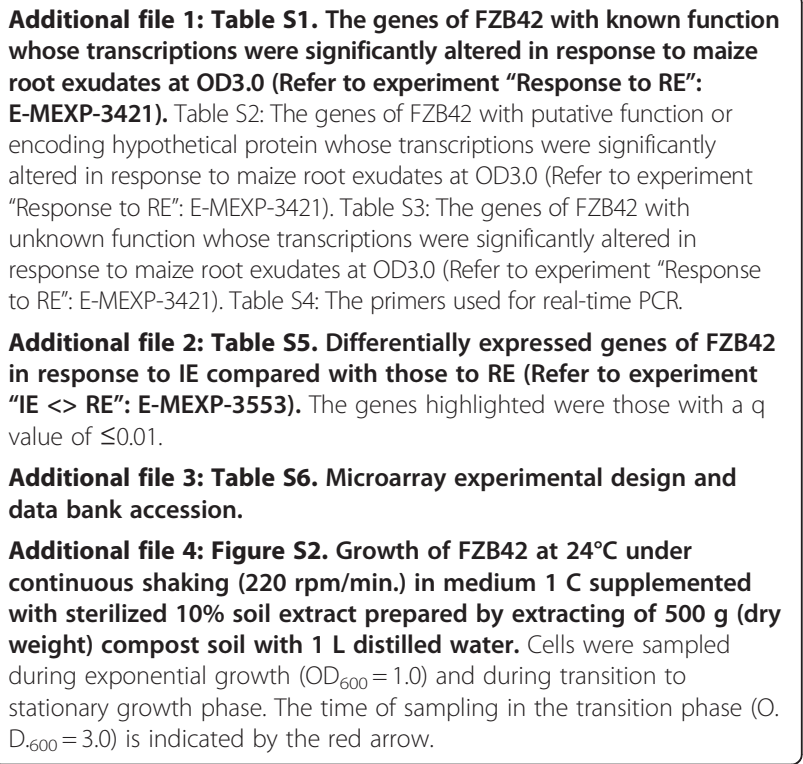

Authors' contributions

BF carried out the main experiments and data analysis and wrote the manuscript draft. LCC performed complementary experiments and revised the manuscript. $A B$ designed the array and was responsible for the hybridization experiments. DF performed the metabolite analysis of root exudates. NvW revised the manuscript. RB guided experimental design and wrote the final version of the manuscript. All authors read and approved the final manuscript.

\section{Acknowledgements}

The financial support for FB by the Priority Academic Development Program of Jiangsu Higher Education Institutions and the National Natural Science Foundation of China (No. 31100081) and the German Academic Exchange Service (DAAD) is gratefully acknowledged, as well as, the financial support given to RB in-frame of the competence network Genome Research on Bacteria (GenoMikPlus, GenoMikTransfer) and of the Chinese-German collaboration program by the German Ministry for Education and Research (BMBF). This study was further supported by the EU-FP6-funded project RHIBAC. We are very indebted to Birgit Baumgarth, Computational Genomics, Center for Biotechnology (CeBiTec), Bielefeld University for performing later hybridisation experiments and support in data processing. We also would like to thank Anne Pohlmann for the excellent assistance in the real-time experiments.

\section{Author details}

'Institute of Forest Protection, Nanjing Forestry University, Longpan Road 159, 210037 Nanjing, China. Institut für Biologie Bakteriengenetik, Humboldt Universität Berlin, Chausseestrasse 117, D-10115 Berlin, Germany. ${ }^{3}$ Molekulare Genetik, Institut für Biologie III, Albert-Ludwigs-Universität Freiburg, Schänzlestrasse 1, D-79104 Freiburg, Germany. ${ }^{4}$ Leibniz Institute for Plant Genetics and Crop Plant Research, Corrensstr. 3, 06466 Gatersleben, Germany. ${ }^{5}$ ABiTEP GmbH, Glienicker Weg 185, D-12489 Berlin, Germany.

Received: 1 April 2012 Accepted: 31 May 2012

Published: 21 June 2012

\section{References}

1. Lugtenberg BJJ, Kamilova F: Plant-growth-promoting rhizobacteria. Annu Rev Microbiol 2009, 63:541-556. 
2. Kloepper JW, Schroth MN: Plant growth-promoting rhizobacteria on radishes. In Proc of the 4th Internat Conf on Plant Pathogenic Bacter. Angers, France: INRA; 1978

3. Domenech J, Reddy MS, Kloepper JW, Ramos B, Gutierrez-Manero J: Combined application of the biological product LS213 with Bacillus, Pseudomonas or Chryseobacterium for growth promotion and biological control of soil-borne diseases in pepper and tomato. BioControl 2006, 51(2):245-258.

4. Alabouvette C, Olivain C, Migheli Q, Steinberg C: Microbiological control of soil-borne phytopathogenic fungi with special emphasis on wiltinducing Fusarium oxysporum. New Phytol 2009, 184(3):529-544.

5. Dessaux Y, Ryan PR, Thomashow LS, Weller DM: Rhizosphere engineering and management for sustainable agriculture. Plant Soil 2009, 321(1-2):363-383.

6. Somers $\mathrm{E}$, Vanderleyden J, Srinivasan M: Rhizosphere bacterial signalling: a love parade beneath our feet. Crit Rev Microbiol 2004, 30(4):205-240.

7. Oger P, Petit A, Dessaux Y: Genetically engineered plants producing opines alter their biological environment. Nat Biotech 1997, 15(4):369-372.

8. Rudrappa T, Czymmek KJ, Pare PW, Bais HP: Root-secreted malic acid recruits beneficial soil bacteria. Plant Physio/ 2008, 148(3):1547-1556.

9. Micallef SA, Shiaris MP, Colon-Carmona A: Influence of Arabidopsis thaliana accessions on rhizobacterial communities and natural variation in root exudates. J Exp Bot 2009, 60(6):1729-1742.

10. Badri DV, Vivanco JM: Regulation and function of root exudates. Plant Cell Environ 2009, 32(6):666-681

11. Shi S, Richardson AE, O'Callaghan M, DeAngelis KM, Jones EE, Stewart A, Firestone MK, Condron LM: Effects of selected root exudate components on soil bacterial communities. FEMS Microbiol Ecol 2011, 77(3):600-610.

12. Diehn M, Relman DA: Comparing functional genomic datasets: lessons from DNA microarray analyses of host-pathogen interactions. Curr Opin Microbiol 2001, 4(1):95-101.

13. Mark GL, Dow JM, Kiely PD, Higgins H, Haynes J, Baysse C, Abbas A, Foley T, Franks A, Morrissey J, et al: Transcriptome profiling of bacterial responses to root exudates identifies genes involved in microbe-plant interactions. Proc Natl Acad Sci U S A 2005, 102(48):17454-17459.

14. Matilla M, Espinosa-Urgel M, Rodriguez-Herva J, Ramos J, Ramos-Gonzalez $\mathrm{M}$ : Genomic analysis reveals the major driving forces of bacterial life in the rhizosphere. Genome Biol 2007, 8(9):R179.

15. Ramachandran VK, East AK, Karunakaran R, Downie JA, Poole PS: Adaptation of Rhizobium leguminosarum to pea, alfalfa and sugar beet rhizospheres investigated by comparative transcriptomics. Genome Biol 2011, 12(10):R106.

16. Bashan $Y$, Holguin G, de-Bashan LE: Azospirillum-plant relationships: physiological, molecular, agricultural, and environmental advances (1997-2003). Can J Microbiol 2004, 50(8):521-577.

17. Steenhoudt O, Vanderleyden J: Azospirillum, a free-living nitrogen-fixing bacterium closely associated with grasses: genetic, biochemical and ecological aspects. FEMS Microbiol Rev 2000, 24(4):487-506.

18. Elizabeth $A B E$, Jo H: Biocontrol of plant disease: a (Gram-) positive perspective. FEMS Microbiol Lett 1999, 171(1):1-9.

19. Chen XH, Koumoutsi A, Scholz R, Borriss R: More than anticipated production of antibiotics and other secondary metabolites by Bacillus amyloliquefaciens FZB42. J Mol Microbiol Biotechnol 2009, 16(1-2):14-24.

20. Idris EE, Iglesias DJ, Talon M, Borriss R: Tryptophan-dependent production of indole-3-acetic acid (IAA) affects level of plant growth promotion by Bacillus amyloliquefaciens FZB42. Mol Plant Microbe Interact 2007, 20(6):619-626.

21. Fan B, Chen XH, Budiharjo A, Bleiss W, Vater J, Borriss R: Efficient colonization of plant roots by the plant growth promoting bacterium Bacillus amyloliquefaciens FZB42, engineered to express green fluorescent protein. J Biotechnol 2011, 151(4):303-311.

22. Lugtenberg BJJ, Dekkers LC, Bloemberg GV: Molecular determinants of rhizosphere colonization by Pseudomonas. Annu Rev Phytopathol 2001 39:461-490

23. Lugtenberg BJJ, Dekkers LC: What makes Pseudomonas bacteria rhizosphere competent? Environ Microbiol 1999, 1(1):9-13.

24. Simons M, van der Bij AJ, Brand I, de Weger LA, Wijfelman CA, Lugtenberg BJ: Gnotobiotic system for studying rhizosphere colonization by plant growth-promoting Pseudomonas bacteria. Mol Plant Microbe Interact 1996, 9(7):600-607.
25. Kraffczyk I, Trolldenier G, Beringer H: Soluble root exudates of maize: Influence of potassium supply and rhizosphere microorganisms. Soil Biol Biochem 1984, 16(4):315-322.

26. Dennis PG, Miller AJ, Hirsch PR: Are root exudates more important than other sources of rhizodeposits in structuring rhizosphere bacterial communities? FEMS Microbiol Ecol 2010, 72(3):313-327.

27. Chen XH, Koumoutsi A, Scholz R, Eisenreich A, Schneider K, Heinemeyer I, Morgenstern B, Voss B, Hess WR, Reva O, et al: Comparative analysis of the complete genome sequence of the plant growth-promoting bacterium Bacillus amyloliquefaciens FZB42. Nat Biotechnol 2007, 25(9):1007-1014.

28. Moszer I, Jones LM, Moreira S, Fabry C, Danchin A: SubtiList: the reference database for the Bacillus subtilis genome. Nucleic Acids Res 2002, 30(1):62-65

29. Yamamoto $H$, Serizawa M, Thompson J, Sekiguchi J: Regulation of the glv operon in Bacillus subtilis: YfiA (GlvR) is a positive regulator of the operon that is repressed through CcpA and cre. J Bacteriol 2001, 183(17):5110-5121.

30. Bais HP, Fall R, Vivanco JM: Biocontrol of Bacillus subtilis against infection of Arabidopsis roots by Pseudomonas syringae is facilitated by biofilm formation and surfactin production. Plant Physiol 2004, 134(1):307-319.

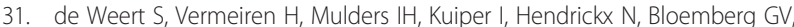
Vanderleyden J, De Mot R, Lugtenberg BJ: Flagella-driven chemotaxis towards exudate components is an important trait for tomato root colonization by Pseudomonas fluorescens. Mol Plant Microbe Interact 2002, 15(11):1173-1180.

32. De Weert S, Kuiper I, Lagendijk EL, Lamers GE, Lugtenberg BJ: Role of chemotaxis toward fusaric acid in colonization of hyphae of Fusarium oxysporum f. sp. radicis-lycopersici by Pseudomonas fluorescens WCS365. Mol Plant Microbe Interact 2004, 17(11):1185-1191.

33. O'Sullivan DJ, O'Gara F: Traits of fluorescent Pseudomonas spp. involved in suppression of plant root pathogens. Microbiol Rev 1992, 56(4):662-676.

34. Walsh UF, Morrissey JP, O'Gara F: Pseudomonas for biocontrol of phytopathogens: from functional genomics to commercial exploitation. Curr Opin Biotechnol 2001, 12(3):289-295.

35. Ongena $M$, Jacques P: Bacillus lipopeptides: versatile weapons for plant disease biocontrol. Trends Microbiol 2008, 16(3):115-125.

36. Raaijmakers JM, de Bruijn I, de Kock MJ: Cyclic lipopeptide production by plant-associated Pseudomonas spp.: diversity, activity, biosynthesis, and regulation. Mol Plant Microbe Interact 2006, 19(7):699-710.

37. Daniels R, Vanderleyden J, Michiels J: Quorum sensing and swarming migration in bacteria. FEMS Microbiol Rev 2004, 28(3):261-289.

38. Capdevila S, Martinez-Granero FM, Sanchez-Contreras M, Rivilla R, Martin M: Analysis of Pseudomonas fluorescens F113 genes implicated in flagellar filament synthesis and their role in competitive root colonization. Microbiology 2004, 150(Pt 11):3889-3897.

39. Combes-Meynet E, Pothier JF, Moenne-Loccoz Y, Prigent-Combaret C: The Pseudomonas secondary metabolite 2,4-diacetylphloroglucinol is a signal inducing rhizoplane expression of Azospirillum genes involved in plantgrowth promotion. Mol Plant Microbe Interact 2010, 24(2):271-284.

40. Ramey BE, Koutsoudis M, Bodman SBv, Fuqua C: Biofilm formation in plant-microbe associations. Curr Opin Microbiol 2004, 7(6):602-609.

41. Surette MG, Miller MB, Bassler BL: Quorum sensing in Escherichia coli, Salmonella typhimurium, and Vibrio harveyi: a new family of genes responsible for autoinducer production. Proc Natl Acad Sci U S A 1999, 96(4):1639-1644

42. Heilmann C, Schweitzer O, Gerke C, Vanittanakom N, Mack D, Gotz F: Molecular basis of intercellular adhesion in the biofilm-forming Staphylococcus epidermidis. Mol Microbiol 1996, 20(5):1083-1091.

43. Gotz F: Staphylococcus and biofilms. Mol Microbiol 2002, 43(6):1367-1378.

44. Huang Z, Meric G, Liu Z, Ma R, Tang Z, Lejeune P: luxS-based quorumsensing signaling affects Biofilm formation in Streptococcus mutans. J Mol Microbiol Biotechnol 2009, 17(1):12-19.

45. Lombardia E, Rovetto AJ, Arabolaza AL, Grau RR: A LuxS-dependent cell-tocell language regulates social behavior and development in Bacillus subtilis. J Bacteriol 2006, 188(12):4442-4452.

46. Branda SS, Gonzalez-Pastor JE, Dervyn E, Ehrlich SD, Losick R, Kolter R: Genes involved in formation of structured multicellular communities by Bacillus subtilis. J Bacteriol 2004, 186(12):3970-3979.

47. Kearns DB, Chu F, Branda SS, Kolter R, Losick R: A master regulator for biofilm formation by Bacillus subtilis. Mol Microbiol 2005, 55(3):739-749. 
48. Chen XH, Koumoutsi A, Scholz R, Schneider K, Vater J, Sussmuth R, Piel J, Borriss R: Genome analysis of Bacillus amyloliquefaciens FZB42 reveals its potential for biocontrol of plant pathogens. J Biotechnol 2009, 140(1-2):27-37.

49. Chen XH, Scholz R, Borriss M, Junge H, Mogel G, Kunz S, Borriss R: Difficidin and bacilysin produced by plant-associated Bacillus amyloliquefaciens are efficient in controlling fire blight disease. J Biotechnol 2009, 140(1-2):38-44.

50. Schneider K, Chen XH, Vater J, Franke P, Nicholson G, Borriss R, Sussmuth $\mathrm{RD}$ : Macrolactin is the polyketide biosynthesis product of the pks2 cluster of Bacillus amyloliquefaciens FZB42. J Nat Prod 2007, 70(9):1417-1423.

51. Koumoutsi A, Chen $X H$, Henne A, Liesegang $H$, Hitzeroth G, Franke P, Vater J, Borriss R: Structural and functional characterization of gene clusters directing nonribosomal synthesis of bioactive cyclic lipopeptides in Bacillus amyloliquefaciens strain FZB42. J Bacteriol 2004, 186(4):1084-1096.

52. Leclere $V$, Marti R, Bechet M, Fickers $P$, Jacques $P$ : The lipopeptides mycosubtilin and surfactin enhance spreading of Bacillus subtilis strains by their surface-active properties. Arch Microbiol 2006, 186(6):475-483.

53. Nicholson WL: The Bacillus subtilis ydjL (bdhA) gene encodes acetoin reductase/2,3-butanediol dehydrogenase. Appl Environ Microbiol 2008, 74(22):6832-6838.

54. Ryu CM, Farag MA, Hu CH, Reddy MS, Wei HX, Pare PW, Kloepper JW: Bacterial volatiles promote growth in Arabidopsis. Proc Natl Acad SCi U S A 2003, 100(8):4927-4932.

55. Blair KM, Turner L, Winkelman JT, Berg HC, Kearns DB: A molecular clutch disables flagella in the Bacillus subtilis biofilm. Science 2008, 320(5883):1636-1638.

56. Mascher T, Hachmann AB, Helmann JD: Regulatory overlap and functional redundancy among Bacillus subtilis extracytoplasmic function sigma factors. J Bacteriol 2007, 189(19):6919-6927.

57. Kreikemeyer B, Mclver KS, Podbielski A: Virulence factor regulation and regulatory networks in Streptococcus pyogenes and their impact on pathogen-host interactions. Trends Microbiol 2003, 11(5):224-232.

58. Beyer-Sehlmeyer G, Kreikemeyer B, Horster A, Podbielski A: Analysis of the growth phase-associated transcriptome of Streptococcus pyogenes. Int J Med Microbiol 2005, 295(3):161-177.

59. Chaussee MA, Dmitriev AV, Callegari EA, Chaussee MS: Growth phaseassociated changes in the transcriptome and proteome of Streptococcus pyogenes. Arch Microbiol 2008, 189(1):27-41.

60. Wieland G, Neumann R, Backhaus $H$ : Variation of microbial communities in soil, rhizosphere, and rhizoplane in response to crop species, soil type, and crop development. Appl Environ Microbiol 2001, 67(12):5849-5854.

61. Buyer JS, Roberts DP, Russek-Cohen E: Soil and plant effects on microbial community structure. Can J Microbiol 2002, 48(11):955-964.

62. Kowalchuk GA, Buma DS, de Boer W, Klinkhamer PG, van Veen JA: Effects of above-ground plant species composition and diversity on the diversity of soil-borne microorganisms. Antonie van Leeuwenhoek 2002, 81(1-4):509-520

63. Broeckling CD, Broz AK, Bergelson J, Manter DK, Vivanco JM: Root exudates regulate soil fungal community composition and diversity. Appl Environ Microbiol 2008, 74(3):738-744.

64. Kuzyakov Y, Raskatov A, Kaupenjohann M: Turnover and distribution of root exudates of Zea mays. Plant Soil 2003, 254(2):317-327.

65. Yang $\mathrm{CH}$, Crowley DE: Rhizosphere microbial community structure in relation to root location and plant iron nutritional status. App/ Environ Microbiol 2000, 66(1):345-351.

66. Wang $Y$, Ohara $Y$, Nakayashiki $H$, Tosa $Y$, Mayama S: Microarray analysis of the gene expression profile induced by the endophytic plant growthpromoting rhizobacteria, Pseudomonas fluorescens FPT9601-T5 in Arabidopsis. Mol Plant Microbe Interact 2005, 18(5):385-396.

67. Mathesius U, Mulders S, Gao M, Teplitski M, Caetano-Anolles G, Rolfe BG, Bauer WD: Extensive and specific responses of a eukaryote to bacterial quorum-sensing signals. Proc Natl Acad Sci U S A 2003, 100(3):1444-1449.

68. Dennis PG, Miller AJ, Hirsch PR: Are root exudates more important than other sources of rhizodeposits in structuring rhizosphere bacterial communities? FEMS Microbiol Ecol, 72(3):313-327.

69. Kuzyakov Y: Priming effects: Interactions between living and dead organic matter. Soil Biol Biochem 2010, 42(9):1363-1371.
70. Haichar FZ, Marol C, Berge O, Rangel-Castro Jl, Prosser Jl, Balesdent J, Heulin T, Achouak W: Plant host habitat and root exudates shape soil bacterial community structure. ISME J 2008, 2(12):1221-1230.

71. Carvalhais LC, Dennis PG, Fedoseyenko D, Hajirezaei MR, Borriss R, von Wiren N: Root exudation of sugars, amino acids, and organic acids by maize as affected by nitrogen, phosphorus, potassium, and iron deficiency. Journal of Plant Nutrition and Soil Science 2011, 174(1):3-11.

72. Brune I, Becker A, Paarmann D, Albersmeier A, Kalinowski J, Puhler A, Tauch A: Under the influence of the active deodorant ingredient 4hydroxy-3-methoxybenzyl alcohol, the skin bacterium Corynebacterium jeikeium moderately responds with differential gene expression. $J$ Biotechnol 2006, 127(1):21-33.

73. DeRisi JL, lyer VR, Brown PO: Exploring the metabolic and genetic contro of gene expression on a genomic scale. Science 1997, 278(5338):680-686

74. Dondrup M, Albaum SP, Griebel T, Henckel K, Junemann S, Kahlke T, Kleindt CK, Kuster H, Linke B, Mertens D, et al: EMMA 2-a MAGE-compliant system for the collaborative analysis and integration of microarray data. $B M C$ Bioinforma 2009, 10:50.

75. Dudoit S, Yang YH, Callow MJ, Speed TP: Statistical methods for identifying differentially expressed genes in replicated cDNA microarray experiments. Stat $\operatorname{Sin} 2002,12(1): 111-139$.

76. Serrania J, Vorholter FJ, Niehaus K, Puhler A, Becker A: Identification of Xanthomonas campestris pv. campestris galactose utilization genes from transcriptome data. J Biotechnol 2008, 135(3):309-317.

77. Benjamini Y, Hochberg Y: Controlling the False Discovery Rate: A Practical and Powerful Approach to Multiple Testing. Journal of the Royal Statistical Society Series B (Methodological) 1995, 57(1):289-300.

78. Roberts PC, El-Gewely MR: Gene expression microarray data analysis demystified. Biotechnol Annu Rev 2008, 14:29-61.

79. Pfaffl MW: A new mathematical model for relative quantification in real-time RT-PCR. Nucleic Acids Res 2001, 29(9):e45.

doi:10.1186/1471-2180-12-116

Cite this article as: Fan et al:: Transcriptomic profiling of Bacillus amyloliquefaciens FZB42 in response to maize root exudates. BMC Microbiology 2012 12:116

\section{Submit your next manuscript to BioMed Central and take full advantage of:}

- Convenient online submission

- Thorough peer review

- No space constraints or color figure charges

- Immediate publication on acceptance

- Inclusion in PubMed, CAS, Scopus and Google Scholar

- Research which is freely available for redistribution 